\title{
Business Assistance for Improving SS Tempeh Production in Islamic Boarding School Limo Depok
}

\author{
Heni Nastiti ${ }^{*}$ \\ ${ }^{1}$ S1 Management Study Program, Faculty of Economy and Business, \\ UPN Veteran Jakarta, Jakarta, Indonesia \\ heni_nastiti@yahoo.com \\ Dewi Cahyani Pangestuti ${ }^{2}$, Noegrahini Lastiningsih ${ }^{3}$ \\ ${ }^{2}$ S1 Management Study Program, Faculty of Economy and Business, \\ UPN Veteran Jakarta, Jakarta, Indonesia \\ ${ }^{3}$ D3 Accounting Study Program, Faculty of Economy and Business, \\ UPN Veteran Jakarta, Jakarta, Indonesia \\ dewichepe@upnvj.ac.id, noegrahini.lastiningsih@upnvj.ac.id
}

(Received December 16, 2021, accepted February 21, 2022)

\begin{abstract}
Tempeh is a kind of food that is favored by many people. Tempeh is native to Indonesia. Tempeh is very easy to be made into any cuisine. Businesses that make tempeh are generally still run on a small scale with limited sales. This is because tempeh producers' abilities and skills are still limited. On the other hand, the market opportunity for tempeh products is still very large. This opportunity can also potential for the tempeh producers who are generally part of lowerclass society to achieve a better standard of living. The problem of market opportunities that are still unreachable by the tempeh producers needs to be addressed through innovation so that the tempeh product can be accepted by the wider market. This is the motivation for the community service team to assist tempeh businesses. Assistance carried out includes improving the quality of the production process. The implementation of community service was carried out at Sirajussa'adah Boarding School in Limo, Depok, from August to September 2021. The methods used are lectures, discussions, training, and mentoring. The result expected from this community service is that tempeh producers, in this case, students of Islamic Boarding School in Limo Depok, can create hygienic tempeh. The conclusion is that, through training and mentoring activities, the students as tempeh business actors can increase their independence. In addition, the production of tempeh can be marketed to the community at large so that the end goal of the program is to increase the business income of Sirajussa'adah Boarding School in Limo Depok..
\end{abstract}

Keywords: business assistance; fulfillments of income market; production increase; tempeh production 


\section{Introduction}

Limo subdistrict, which is located in the buffer zone of the southern part of Jakarta, consists of six neighborhoods, 106 Rukun Warga (RW) and 627 Rukun Tetangga (RT) with a population of 240,920 people with livelihoods mostly in the trade sector, which is $38.2 \%$ of the population. For this reason, the existing business fields as a source of additional income in the community need to be optimized and their management improved. Persistence, tenacity, and perseverance in empowering human resource assets need to be balanced with the provision of counseling, assistance, technology, and economic institutions to improve the amount of production, quality, distribution of sales, packaging, business results, capital, equipment, and other supports.

Sirajussa'adah Islamic Boarding School is a private Islamic institution. Initiated in 2007, then established as a boarding school on Wednesday, May 9, 2012, M/18 Jumadil Akhir 1433 by Mr. K.H. Abdurrahman by using the Salafiyah Education method for Islamic boarding school and formal education.

Many individuals enjoy tempeh. Tempeh is an Indonesian cuisine that has been around for a long time. Tempeh is a versatile ingredient that may be used in a wide range of recipes. Small enterprises that produce tempeh usually have sales that haven't been able to meet the demands of the surrounding community and potential markets and are still mostly done on a small scale.

In order to equip santri (student of Islamic boarding school) with the ability to run independent businesses, Sirajussa'adah Islamic Boarding School has built business units that are handled and carried out by the santri of Sirajussa'adah Islamic Boarding School. Alhamdulillah, the efforts of the students in the production of SS tempeh have been running smoothly, so in addition to providing benefits for the students, it is also helping the community get hygienic and high-quality tempeh. The SS tempeh is made from soybeans and is made hygienically. It can now be enjoyed by the people of Limo and its surroundings. Meanwhile, the current production of tempeh by the students has reached $170 \mathrm{~kg}$ of soybeans per day, and all of this is handled by the santri of the Sirajussa'adah Islamic Boarding School. Improvements are continued to be made in the SS tempeh production process to overcome obstacles and problems that often occur in order to help improve the welfare of the students. 
The SS tempeh business in Limo Depok is one of the tempeh productions that has been running for a long time, starting in the 1900s until now in Jakarta, with several home industries and approximately 1000 private houses. The average amount of tempeh produced every day is 50 $\mathrm{kg}$ per household. Many local people have a high interest in consuming tempeh. Tempeh sales are directly distributed to sellers of vegetable stalls and local traditional markets. Because the demand for tempeh is very high, the production of SS tempeh continues to be controlled. The SS tempeh manufacturing is students' business and the production of SS tempeh provides benefits for the students as well as provides the community to get hygienic and high-quality tempeh.

There is still a lack of understanding of how to increase income and to develop business among the personnel of SS tempeh producers. They lack knowledge and business or management skills in the fields of production, marketing, and sales of products from their business. Sirajussa'adah Islamic Boarding School has only been running its business for the past few months.

The potential market share will be extremely beneficial to the tempeh producers. To tap this potential, proper system that regulates the production process, business management, and marketing to ensure that the business runs smoothly and in accordance with the desired mechanism, business management, and marketing. Thus, it will be easy to implement business management so that it runs smoothly, orderly, and successfully even though the business was originally small. Increasing the variety of product and variations in shape, type, and taste of tempeh are beneficial so that consumers will have many choices. Meanwhile, good packaging model will present the goods to be as neat, clean, and attractive as possible. Good packaging is also greatly influences the interest of buyers because the product's appearance looks attractive and hygienic.

\section{Literature Review}

According to Kosieradzka (2017), production management is defined as the sequence of various activities in producing goods and services through the process of changingfrom input to expenditure. Quality is the physical condition of the product, product function, and the nature of a product that can satisfy consumer tastes and meet consumer needs by comparing the value of money spent to have the product. According to Mrugalska \& Wyrwicka (2017), quality itself has the meaning of control activities carried out in measuring product quality characteristics, 
making comparisons with specifications or requirements, and providing results to take health actions in accordance with established standards if there are differences in appearance.

Some opinions related to the notion of quality include: (1) Agyekum et al., (2015), quality is precisely the purpose or benefit of a product (2) Pedram \& Balachander (2015) quality is the accuracy of a product in meeting needs which include availability, delivery, reliability, maintainability, andcost effectiveness. (3) Moraes et al., (2020) quality has the aim of being able to meet consumer needs for now and in the future. (4) Chenavaz \& Jasimuddin (2017) quality is a characteristic possessed by products and services where it consists of marketing, engineering, manufacture, and maintenance, these products and services provide conformity to consumer needs and consumer expectations in their use. (5) Mitra (2016) quality itself is determined by the customer, where customers have the products and services they want and these products and services are in accordance with customer needs and achieve expectations at a certain price level that gives an assessment of the product. (6) Elliot (2013) quality is something that results from products and services where different values for different people and this also depends on time and place, can also be adjusted to the purpose. (7) Kosieradzka (2017) quality is where the dynamic conditions of products, services, people, processes, and the environmentthat can meet or exceed expectations. (8) The difference between the terms ISO 8402 and the Indonesian National Standard (SNI 19-84021991), quality is the overall characteristics of a product or service that can satisfy the needs of customers, stated directly or impliedly. Requirements can be defined as the specifications that have been stated in the contract as well as the criteria that have been defined previously.

According to Mitra (2016), control is an activity that provides guarantees that the activities and production operations carried out are in conformity with what is expected. If there are deviations that occur, the deviations can be corrected and the things that were hoped for can be achieved by the businessman. Agyekum et al., (2015) define quality control as an engineering and management activity in which product quality characteristics are measured and compared to specifications or statements.

The goals of a quality control:

1. The aims and objectives of quality control are: (a) the quality standards of goods produced are as expected. (b) to a very small extent, reduces inspection costs. (c) Minimize the cost 
of the machine and also the process so that the production quality can be very small. (d) As much as possible, reduce production costs. (Idris et al., 2018)

2. Quality control has the aim of improving product quality, maintaining product quality, and minimizing damaged materials. (Supriyadi et al., 2017)

3. Quality control has the following objectives: (a) There is an increase in consumer decisions. (b). Maximize costs by trying to make the costs as small as possible. (c). The selection carried out is in accordance with the time that has been carried out. (Cheng et al, 2018).

As an academician, in carrying out the duties of Tri Dharma, higher education lecturers are obliged to provide community service, and this time the service is in the form of counseling, training, and assistance to improve business by increasing the amount of production, quality of production, marketing, and sales of tempeh. With those in mind, this community service aims to provide counseling, training, and assistance to improve the production of SS tempeh at Sirajussa'adah Boarding School Limo, Depok.

\section{Methods}

To achieve the targets and outputs according to the problems faced, several methods are utilized, which include business quality management counseling, training on hygienic packaging manufacture and sales practices, quality packaging manufacturing, business licensing, mentoring and evaluation monitoring. Details of the complete method of carrying out activities are presented in Table 1.

In the implementation of this community service activity, the service team partnered with Sirajussa'adah Boarding School, in this case, students, as business actors, in order to equip them with entrepreneurship skills after the completion of their education. In the implementation stage of community service programs, partners participate in 1) providing information about the problems faced, 2) providing permits to the Faculty of Economics and Business of UPN Veteran Jakarta, and 3) signing a willingness to accept community partnership programs. 4) facilitate and provide a location for training and learning, 5) The student, as a tempeh maker business actor, actively participates in community service activities. 
Table 1. Methods of implementation of community service activities

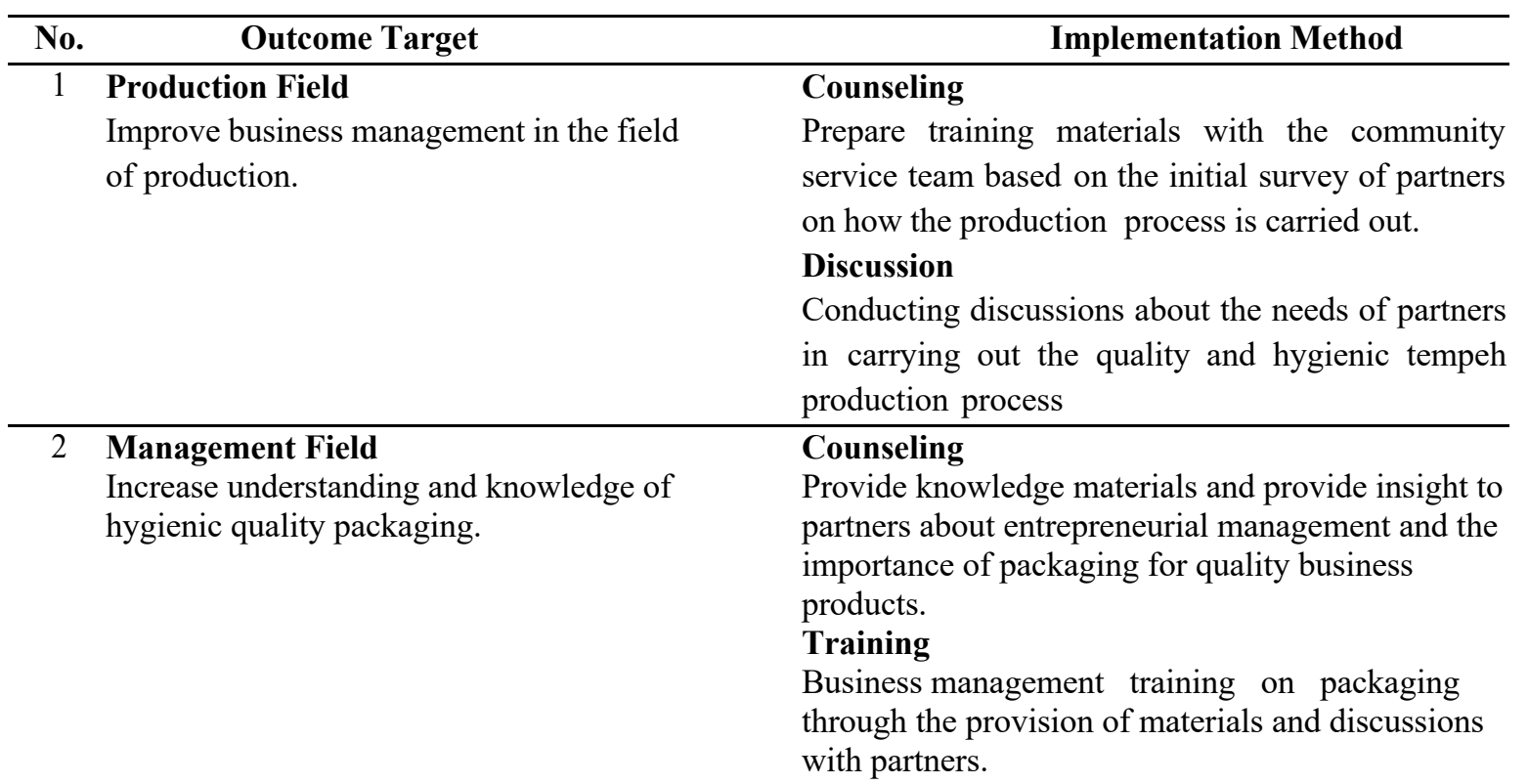

\section{Marketing}

Increase the number of sales of products made with packaging of various sizes, shapes, and quality.

\section{Technology Transfer}

To facilitate training and practice of stripping soybean raw materials and packaging adhesives.

\section{Training}

Demonstration and training is done with simulations and demonstrations of packaging manufacture and sales management practices using existing equipment prepared by the community service team. The training is carried out by the community service team, followed by the participants.

\section{Bookkeeping}

\section{Counseling}

Counseling and assistance on bookkeeping for the number of raw material needs, inventory, and raw material purchases and use, as well as income and expenses, production and sales results.

\section{Training}

Training on recording income and expenses, production and sales results and income.

5 Production Practice and Assistance in
Increasing the Number of Production and
Hygienic Productions are followed by all
members of the community service Team.

\section{Mentoring}

This activity is carried out periodically to foster and assist partners to successfully carry out the practice of increasing the production of hygienic products to support increasing sales.

6 Scientific articles which will be published in Compiled from the results of counseling, training, the Journal discussion, and mentoring.
Compiled from the results of counseling, training, practice, and other library sources.

In the implementation of this community service activity, the service team partnered with Sirajussa'adah Boarding School, in this case, students (santri), as business practicioners, in order to equip them with entrepreneurship skills after the completion of their education. In the 
implementation stage of community service programs, partners participated in 1) providing information about the problems faced, 2) providing permits to the Faculty of Economics and Business of UPN Veteran Jakarta, and 3) signing a willingness to accept community partnership programs. 4) facilitate and provide a location for training and learning, 5) The student, as a tempeh producers, actively participates in community service activities.

\section{Results and Discussions}

Based on the results of the survey and initial questionnaires that have been distributed to the SS tempeh production personnel in Sirajussa'adah Boarding School, it stated that $55 \%$ of respondents expressed the problems experienced. They did not have knowledge and insight into production, packaging, and sales skills and did not understand the bookkeeping of sales results. To overcome these problems, the community service team suggested and implemented a solution in the form of counseling and management assistance in production so that it would provide higher economic value.

SS tempeh management still needs continuous assistance (multi-years). It is expected that later it will produce a model that consists of a marketing distribution strategy, standardization of production processes, and accounting standards (finance). Community service output comes in the form of a patent filing for the SS tempeh production process. Counselling and mentoring activities were carried out for SS tempeh producers at Sirajussa'adah Boarding School, and they had been carried out for 4 (four) months.

The activity began with an initial survey at the end of February 2021. Furthermore, coordination with partners and counseling preparations were carried out. From June 21 to July 26, 2021, extension activities were carried out for production management, packaging, bookkeeping, and finance. And from August 2 to September 20, 2021, direct assistance was carried out in the production process, packaging manufacturing, bookkeeping, and finance.

\section{Counselling Process}

In the counseling, the service team delivered material about the process of making hygienic tempeh production. The methods carried out to support counseling were by lectures, interviews, and discussions related to problems. During this time, the manufacture of tempeh done in the traditional way was quite simple but has a great risk of failure if not done by 
experienced people. In addition, the fungus in tempeh did not grow evenly and was blackish or gray in color. As a result, the tempeh would be less clean and less hygienic.

Inside the counseling material, the service team explained the conditions of making hygienic tempeh, among others:

1. Employee hygiene. It is required to maintain body hygiene and use complete work clothes and other accessories such as head coverings, gloves, and work shoes. It is required to always wash your hands with soap before processing food, after processing raw materials or dirty materials/tools, and after getting out of the toilet.

2. Cleanliness of the production equipment used in the production process. The equipment used in the production process is made of non-rusty, strong, and easy-to-clean materials. To make working and cleaning easier, production equipment should be organized in the order in which it is used.

3. Environmental cleanliness. Free from pest animals, especially rodents such as rats. Not in an environment close to a landfill, either solid or liquid waste, or in an environment where there is a buildup of garbage.

4. Cleanliness of the product. Materials and tempeh produced are stored in a clean and dry place or room.

In this counseling activity, a pretest was done to find out how during this time, participants (15 people) make tempeh. From the results of the pretest, there were still many personnel who do not understand the safe way to carry on production process of tempeh hygienically. And after received counseling about the manufacturing of tempeh, the hygienist then conducted a posttest to find out if the participants were already understood the material given about the manufacturing of tempeh. From the results of posttests, there is an increase of $25 \%$ in the number of personnel who understand the production process of tempeh hygienically.

\section{Assisting Production Process}

The training and mentoring were given to the participants to hone their skills in running the production process of tempeh. Training and mentoring in practice were conducted directly in the field. The general production process can be elaborated in these steps; the raw material for tempeh is made from soybeans. Soybeans are soaked in hot water and then washed in cold water. Tapioca flour and tempeh yeast (Rhizopus oligosporus) are added to the fermentation 
process. Then soybeans are washed and boiled using a saucepan and a stick. While wind is used for cooling, it is assisted by a fan.

Training and mentoring to make hygienic tempeh were held on August 2, 2021. After this training, discussions were held with partners about the implementation of training and mentoring on how to make hygienic tempeh that has been implemented. The process of making tempeh hygienically is as follows: 1) Soybean soaking is done before the soybeans are boiled. This soy immersion lasts for approximately 14 hours. The goal of this process is to facilitate fermentation; 2) soy boiling lasts approximately 2 hours; and 3) after boiling, the soybeans are cooled. Once the soybeans are completely cold, they are given yeast. The distribution process is covered with plastic for approximately 2 days. After 2 days, tempeh is ready to be marketed.

Training and mentoring for tempeh marketing was held on September 20, 2021. After training and mentoring, discussions were held with partners regarding the implementation of tempeh marketing training and assistance that has been implemented. With the training, the team finally know some of the following things: 1) In the event of training on marketing, partners feel enlightened, because so far the marketing carried out is still very limited. 2) Tempeh marketing training and mentoring is considered very useful to increase knowledge in an effort to expand marketing.

The production of tempeh in Indonesia is still largely done in the traditional way and the simple way. Producers come from the household industry that still uses equipment and production processes that are not standard. In this training, the service team provided a method of making a hygienic tempeh process. The ingredients and production process of SS Tempeh include ingredients consisting of selected soybeans, yeast, and sago flour, while the production process equipment consists of: a peeler machine, washing machine, steamer, soaking vat, fermenter, box container, and bucket. While the process of making SS tempeh Sirajussa'adah Boarding School Limo Depok goes through several stages,
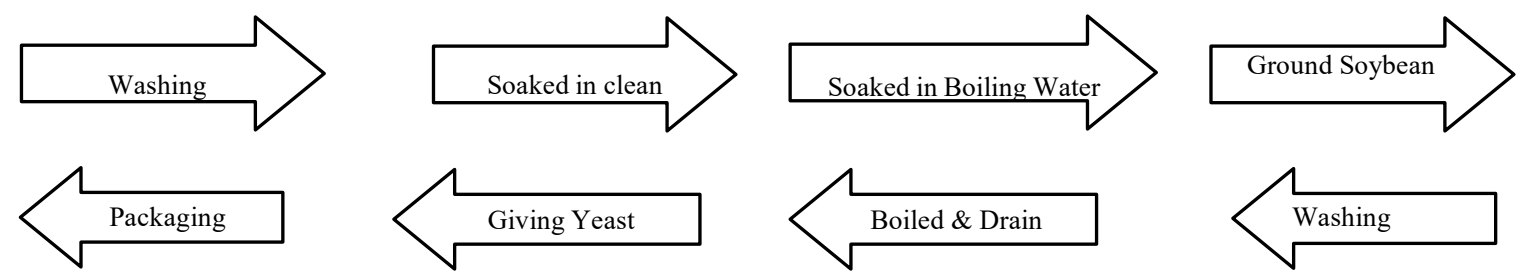

Fig. 1. Tempeh production process flow 
The process of producing tempeh begins with repeatedly washing dry soybeans with clean water until they are completely clean, so that they are free from dirt and uncleanness. After that, the soybeans are soaked in clean water until they expand completely, which takes about 8 hours. Then the soybeans are soaked in boiling water for 20-24 hours, so that the soybeans release lactic acid as a medium for mushroom growth. Then the soybeans are ground with a skin-breaking and separating machine so that the soybeans are completely separated or clean from the skin to produce quality tempeh. Then the soybeans are washed using a washing machine and also clean water until they are completely clean and the sour taste is gone. After that, the soybeans are boiled until cooked and then drained.

After that, the soybeans are cooled and dried using a fan. After being cooled and dried, the soybeans are mixed with yeast that has been mixed with sago flour as an adhesive, and stirred until evenly mixed. Then the soybeans that have been given yeast are sifted to separate them from the seeds so that the resulting tempeh actually uses pure soybeans and produces a delicious taste.

Then the soybeans enter the packaging stage according to the predetermined size. The last process is that the packaged soybeans are arranged on the racks that have been provided and then left for 36-40 hours, or what is commonly called the fermentation process, until they become perfectly cooked tempeh and are ready to be marketed.
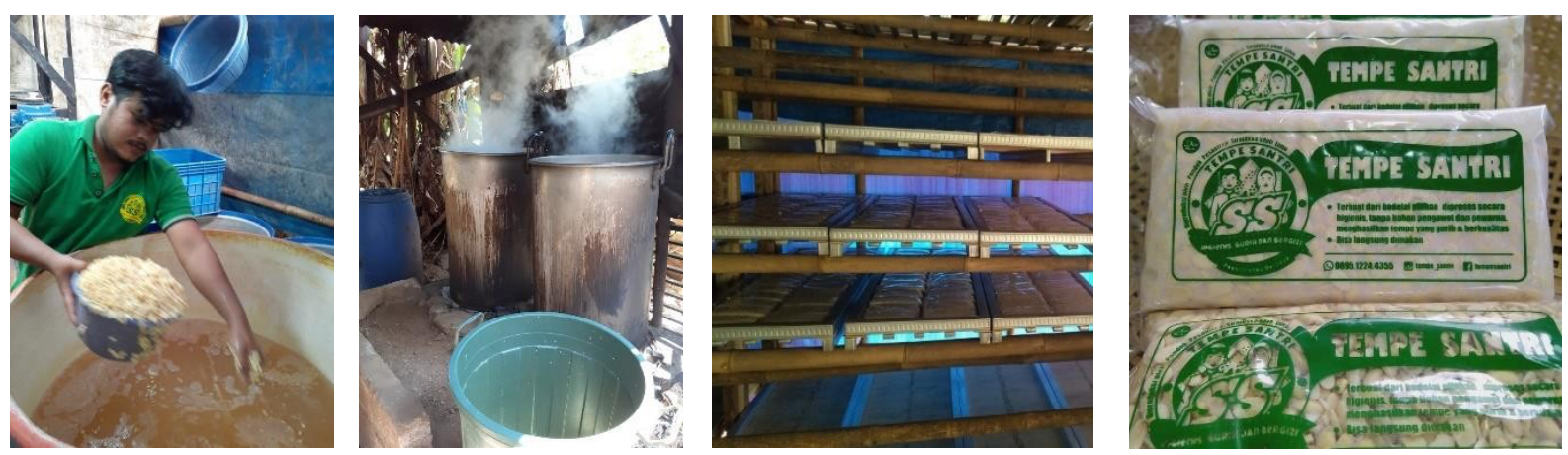

Figure 2. SS Tempeh Manufacturing Process

This community service activity went smoothly. Supporting factors in this activity are positive things that affect the success of community service programs, namely: 1) positive responses from partners, so that this community service program can be implemented properly; 2) the commitment and cohesiveness of the community service implementation team; and 3) support 
and provision of adequate facilities from UPN Veteran Jakarta in the implementation of community service.

However, technically, there are some obstacles found during the series of community service implementations, and if there will be an evaluation and improvement for community service activities in the future. These constraints are schedule changes that have previously been agreed upon so as resulted in delays and mergers of activities that had previously been planned. This community service activity took place during the COVID-19 pandemic, so the team was very careful and implemented very strict health protocols. In addition, there were restrictions on participants that affected the assistance schedule being carried out, which could not be done simultaneously.

\section{Conclusion}

The implementation of counselling and assistance to the SS tempeh production at the Sirajussa'adah Islamic Boarding School in Limo Depok had been going according to plan. Participants understand the good practice of tempeh production. The target to achieve in this activity can be seen from the results of the pre-test and post-tests, which showed that knowledge and insight into the benefits of the production process and hygienic production methods to increase the selling value of the products, meaning that the participants of counseling, training, and assistance understood the material provided and will perform hygienic production process to increase their sales. From the results of the community service, the team suggested that the personnel in the production of SS tempeh at the Sirajussa'adah Islamic Boarding School, Limo, Depok, be as follows: supervision must be carried out on the procedures for the steps involved in making SS tempeh; training must be carried out for workers with the aim of increasing their abilities so that they will improve the quality of the tempeh produced.

\section{Acknowledgements}

This community service can be carried out well thanks to the help of various parties. For that, the community service team thanks LPPM UPN Veteran Jakarta as a service affiliate, Mr. KH. Abdurrahman as the leader of Sirajussa'adah boarding school who has provided good cooperation in community service, and those who we cannot name one by one who have helped so that this community service ran smoothly. 


\section{References}

Agyekum, C. K., Haifeng, H., Agyeiwaa, A., Agyekum, C. K., Haifeng, H., \& Agyeiwaa, A. (2015). Consumer perception of product quality. Microeconomics and Macroeconomics, 3(2), 25-29.

Chenavaz, R. Y., \& Jasimuddin, S. M. (2017). An analytical model of the relationship between product quality and advertising. European Journal of Operational Research, 263(1), $295-307$.

Idris, I., Sari, R. A., Wulandari, W., \& Wulandari, U. (2018). Pengendalian Kualitas Tempe Dengan Metode Seven Tools. Jurnal Teknovasi: Jurnal Teknik Dan Inovasi, 3(1), 6680 .

Kosieradzka, A. (2017). Maturity model for production management. Procedia Engineering, $182,342-349$.

Mitra, A. (2016). Fundamentals of quality control and improvement. John Wiley $\backslash \&$ Sons.

Moraes, F., Yang, J., Zhang, R., \& Murdock, V. (2020). The role of attributes in product quality comparisons. Proceedings of the 2020 Conference on Human Information Interaction and Retrieval, 253-262.

Mrugalska, B., \& Wyrwicka, M. K. (2017). Towards lean production in industry 4.0. Procedia Engineering, 182, 466-473.

Pedram, M., \& Balachander, S. (2015). Increasing quality sequence: when is it an optimal product introduction strategy? Management Science, 61(10), 2487-2494.

Supriyadi, S., Ramayanti, G., \& Roberto, A. C. (2017). Analisis kualitas produk dengan pendekatan six sigma. Repository Universitas Serang Raya, D7--D13. 